\title{
Commentary on "The Use of Econometric Methods in the Analysis of Centrally Planned Economies: The SRI-WEFA Experience" by Donald W. Green
}

\author{
HAROLD T. SHAPIRO
}

Department of Economics, University of Michigan, Ann Arbor, Michigan 48109

There are a number of quite distinct dimensions to Donald Green's paper and although the various subjects are not quite disjoint, I think our discussion may benefit from some separation of the key issues. Most importantly, the paper is a report, in summary form, of the initial fruits of the SRI-WEFA project on the construction of an econometric model of the Soviet economy. This project has already produced significant new contributions in the area of macroeconometric model building and to our understanding of the Soviet economic system; since Dr. Green has been a key contributor to this effort from its inception, his report, together with his reflections and analyses, is quite welcome. The paper, however, also addresses a number of more generai methodological issues concerning the use of dummy variables and the relationship between theory and data that are not particularly associated with the SRI-WEFA experience in econometric modeling of centrally planned economies. These issues are, of course, relevant to almost any empirical investigation; Green's discussion in this area, however, adds little insight either to what we already understand about these issues, or to our understanding of the evolution of the Soviet economy. Unfortunately, in this paper Green spends relatively a lot of time on these methodological issues. Thus, the paper is disappointing in that it yields too little information on the major accomplishments of the SRI-WEFA group, the construction, evaluation, and use of SOVMOD III, while providing a generally uninformative (and at times confusing) discussion of certain methodological issues. I turn first to a discussion of some of these issues and then turn my attention to the most interesting issues surrounding SOVMOD III.

By and large, the discussion on methodology is confusing and unnecessary. For example, Green introduces unnecessary and rather confusing new terminology (technological, statutory, and behavioral regularity) to refer to the issue of stability of the mechanism generating the data. Likewise, the introduction of such terms as contingency response and central intervention in an attempt to address an important problem simply manages to further confuse the issues. They create more problems than they help us solve. As Green points 
out, stability in both process and measurement is a necessary condition for the application of econometric procedure, but his discussion seems to contain some confusion and erroneous connection between this and the notion of agent rationality or the optimality of agent behavior. Econometric procedures, whether applied to market economies or planned economies, do not rely on agent (micro- or macro-) behavior that is optimal in any sense. From an econometric point of view, the "law of large numbers" is indistinguishable from the "law of large organization." We all use "rules of thumb" which may or may not be approximately optimal, but the issue for econometrics is simply stability of relationships. There are, of course, different institutional relationships characterizing market and Soviet systems and this certainly has an effect on the specification of econometric models. But Green seems to have guided us down an unproductive path with the development of this particular typology. It would have been much more productive to learn how Green and his colleagues dealt with certain changing aspects of the Soviet economy. For example, it is widely accepted that the Soviet system of economic management has slowly changed over time. The independence of enterprises is growing and in addition to direct instructions regulating their activity, they are expected to respond increasingly to such factors as prices, profits, taxes, etc. These changes must have transformed certain behavioral relationships (whether contingency responses or central interventions), and it would have been most interesting and revealing to understand how such changes were accommodated within the structure of SOVMOD III.

I find nothing objectionable in the section of the paper dealing with the assessment of the use of dummy variables within this particular experiment. Indeed, it provides indirectly quite a bit of information on how SOVMOD III handles some very difficult substantive problems. It is largely uninformative, however, on the more general methodological issues it raises.

The section of Green's paper on "The Role of Theory: A Kuhnian Perspective," I find rather trying. But then, I find the whole proliferation of discussions surrounding methodology rather tiresome. It does contain some useful reflections on the problems confronted by the research team and their creative response to them. It would be more revealing, however, if we did not feel obligated to put the story in a Kuhnian perspective. The "positivist fable" (as presented by Green) is not the framework within which any serious researchers in quantitative economics operate. The creative interplay between theory and data has always characterized relevant empirical science (well illustrated by the dynamic evolvement of SOVMOD III) and we all understand, therefore, that econometrics is part hypotheses searching and part hypotheses testing. Hypotheses searching and testing are not only both legitimate research activities but necessary research activities in empirical science and we need not be embarrassed about pursuing both as long as we are clear about what we are doing. It is a natural part of almost all empirical 
investigations and, not surprisingly, SRI-WEFA researchers find they had to do both. It is perhaps true that the "posture" of many journal articles is one of hypothesis testing, but whatever the explanation of this posture, it has little relation to the actual nature of useful research being carried out. Technical virtuosity has become part of graduate training in economics not because we believe the positivist fable, but because many of us need these tools as aids in all aspects of our work.

I turn now to the construction of SOVMOD III itself and to the general context within which this research effort took place. Macroeconometric model building in the centrally planned economies of the Soviet Union and Eastern Europe got off to a relatively late start. Although there is now quite an intense and productive level of activity in certain research centers, during the period when macroeconometric models were becoming well established as aids to forecasting and policy analysis in many of the advanced market economies activity in the Soviet Union and Eastern Europe was confined to the work of a few "pioneers" in Poland, Hungary, and Czechoslovakia (see Shapiro and Halabuk (1976)). At the same time, Western scholars, with limited access to appropriate data, pursued their analysis of the Soviet economy along different lines. One notable exception was the work of Niwa (1971), but his models confronted rather specific issues and did not adequately model the system as a whole. The SRI-WEFA experiment (based on a combination of official Soviet data and "Western reconstruction" of official data) was inaugurated more or less contemporaneously with a new and more intensive level of activity and research in this same area among scholars in the Soviet Union and Eastern Europe. This latter effort has now produced a new generation of macroeconometric models of centrally planned economies that is quite impressive. In Poland there is work of Kudrycka (1974) and Lapinska-Sobchak (1974) in addition to the continuing work of Maciejewski (1975), Maciejewski and Zajchowski $(1973,1974)$ at the Commission of Planning, and Welfe $(1973$, 1975) at the Institute of Econometrics and Statistics at the University of Lodz. In Hungary, we have the efforts of Nagy (1974) (a small but interesting attempt to use inventories as the buffer bringing the system into balance), and Simon (1974) (a model constructed primarily as a vehicle to study foreign trade flows) as well as the continuing work of Halabuk (1973) and his staff at the Econometrics Laboratory of the Central Statistical Office-the original pioneers in this area. In Czechoslovakia there is the work of Šujan et al. (1973) (on medium-term models), and in the German Democratic Republic the continuing work of Wölfling $(1970,1973)$. Currently there are also some interesting new experiments in connection with the Yugoslav economy-an experimental model by Babić (1974) and a new model being developed by Mencinger (1975). In the Soviet Union we currently have the efforts of Yemelyanov and Kushnirski (1970) (which attempts to combine econometric models with various types of optimizing models and alternative sources of 
information), the work of Adirim et al. (1975) (dealing with Latvia), and the work of Levickij et al. (1972). Finally, there is the current research of Menshikov and others being undertaken at UNCTAD in New York, on econometric models of the Soviet Union and Eastern European Countries. Although there still remains some scarcity of information on the precise nature of the work being done, there have been a number of conferences organized by the Computing Research Center UNDP in Bratislava, Czechoslovakia, and more recently by the Institute of Econometrics and Statistics of the University of Lodz and the Central Statistical Office in Warsaw. These conferences have concerned themselves with various issues of model specification as well as with the evaluation of model forecasts and other dynamic characteristics of particular econometric models. Although the main focus of this work is to produce a tool of analysis to aid in the process of plan formation, these models are also being used increasingly to monitor and adapt to changes in the current plan.

Macroeconometric models of socialist countries can be expected, of course, to reflect not only the direct importance of central planning in the evolution of the economy, but the potential roles these models might play or the uses they might have in the planning process. The following key features characterize most macroeconometric models that have been developed for these countries. (1) Medium- to long-term outlook (following the basic framework of the plan). (2) Annual data based on some version of the Material Product System of Accounts. Thus, attention is focused on "real" (volume) flows and stocks and on the "productive" sector. (3) Heavy emphasis on the supply of output by industry, assuming full employment of capital and labor. Thus there is normally little role allowed in the models for capacity utilization. (4) Only modest concern with the complete allocation of production to end use. Finally, until recently most models contained no mechanism for the explicit introduction of government policy variables (plan data or budget data) or adequate articulation of the economy's various adjustments mechanisms. Perhaps all key policy decisions were thought to be represented by the exogenous allocation of factors to various industries; if adjustments were necessary they were made in advance through this allocation. It is precisely in these latter areas where the SRI-WEFA group has made such an outstanding contribution (introducing a rich array of plan and budgetary data) and where a number of contemporary efforts in Eastern Europe are concentrated (e.g., Maciejewski and Zajchowski, (1973, 1974)). There are also some current attempts to integrate input-output models and econometric models. Thus, the SRI-WEFA experiment neatly parallels in some respects these contemporary efforts in the Soviet Union and Eastern Europe.

SOVMOD III is the current embodiment of the SRI-WEFA efforts in modeling the Soviet economy. It has been an outstanding effort that has produced a model of high quality, which presents many new challenges to researchers in this area. Among the interesting new features of this model are 
its use of annual plan data as anticipatory variables, detailed treatment of aggregate demand (including appropriate supply constraints), and the detailed attention devoted to actual State budget allocations. In no other model is the institutionalized structure of central planning so evident. Further, as far as I know, it is also the most extensively tested of any of these models and has already been used to generate forecasts, on an experimental basis, to the year 1990 , as well as a whole set of interesting policy simulations. In addition, it contains a number of interesting alternatives for dealing both with the balancing of demand and supply - an issue almost ignored in earlier modeling of centrally planned economies-and the determination of the effective level of employment of the principal factor inputs. Full employment of factor inputs is an assumption in most of the official data, but it is obviously critical to determine the true measure of factor utilization. In short, SOVMOD III represents quite an achievement in innovative model building, from data construction through model evaluation and use. It is disappointing, therefore, that so few details on a number of the innovative steps introduced are discussed in Green's paper.

These various reservations, however, do not in any way affect my overall admiration for the contribution of Donald Green and his collaborators, by the creation of SOVMOD III, both to the area of comparative economics and to econometrics. It improves our understanding of both the operation of the Soviet economy and the capacity and potential of macroeconometric models.

\section{REFERENCES}

Adirim, I. G. et al., A System of Forecasting Models of the Economic Growth of the National Economy of a Republic (in Russian). Riga:Zinatnie, 1975.

Babić, Mate, Ekonometrijski model Jugoslavenske privrede [Econometric Model of the Yugoslav Economy]. Zagreb: Ekonomski institut Zagreb, 1974.

Halabuk, Laszlo, Hulyák, K., Nyáry, Zs., and Kotász, Gy., "The M-2 Econometric Model of the Hungarian National Economy." Budapest: Akademiai Kiado, 1973

Kudrycka, I., "Econometric Model of National Economy." Contributed paper, European Conference of the Econometric Society, Grenoble, Sept. 1974.

Lapinska-Sobchak, N., "A Model of the Financial Sector of the Polish National Economy." Paper presented at Sbornik doklodov vtorogo mezhdunarodnogo symposiuma po primeneniyu prognosticheskick modelei v socialisticeskom khozyaystve, Bratislava, Dec. 29-31, 1974.

Levickij, E. M., Menshikov, S. M., and Ozerova, O. Yu., "An Input--Output Model of the USSR." In Dynamic Models of the Economy (in Russian). Novosibirsk: Research Institute of Industrial Economics of the Academy of Sciences of the USSR, 1972.

Maciejewski, W., "Possibilities of Application of Simulation Methods in Econometric Models for the National Economy, in the Process of Plan Formation." State Planning Commission, Warsaw, Poland. Paper presented to the Econometric Society Third World Congress, Toronto, Canada, Aug. 1975. 
Maciejewski, W., and Zajchowski, J., "Experimental Application of the Econometric Model of the Polish Economy to Simulation Purposes of the Economic Growth."Gospodarka Planowa No. 9, 1973.

Maciejewski, W., and Zajchowski, J., "Econometric Model of the Polish Economy KP-2, Primary Results." Warsaw: Computer Research Center, Commission of Planning, 1974.

Mencinger, J., "An Econometric Model of Yugoslavia." Ph.D. dissertation, University of Pennsylvania, 1975.

Nagy, S., "The Technical Progress Represented in an Econometric Model." Statisztikai Szemle $52,7: 627-640,1974$.

Niwa, H., "An Econometric Analysis and Forecast of Soviet Economic Growth." In Peter J. D. Wiles, ed., The Prediction of Communist Economic Performance, pp. 339-372. Cambridge: Cambridge Univ. Press, 1971.

Shapiro, Harold, T., and Halabuk, Laszlo, "Macro-Econometric Model Building in Socialist and Non-Socialist Countries: A Comparative Study." Internat. Econ. Rev.17:529-565, Oct. 1976.

Simon, A., "The Analysis of the Hungarian Foreign Trade Using Econometric Methods." Szigma 7:165-176, 1974.

Šujan. I., Kolek, J., Gergelyi, K., et al., "Short-Term Prognostic Model of the National Economy. Computable Econometric Model of Quarterly Prognostic Values Comprising Selected Indexes of the Czechoslovakian National Economy." Vyzkumne Vypočtove Středisko, Bratislava, 1973.

Welfe, W., "A Medium-Term Econometric Model of the Polish Economy." Paper presented to the European Meeting of the Econometric Society, Oslo, Norway, Aug. 1973. Lodz: Prace Instytutu Ekonometrii i Statystyki Uniwersytetu Lodzkiego, Seria D. Nr. 2, 1973.

Welfe, W., Forecasting Econometric Models of the Polish Economy; Their Structure and Use in Planning and Economic Policy Simulations. Lodz: Institute of Econometrics and Statistics, 1975.

Wölfling, M., "On the Application of Economic Models of the Economy of the GDR." Mimeographed. Berlin, 1970.

Wölfling, M., "Problems of Shaping the Main Proportions of the National Economy by Means of a Model." Rough translation. Berlin, 1973.

Yemelyanov, A. S., and Kushnirski, F. I., "Dynamic Model of the Econometric Type for the Ukrainian SSR." Thesis Report at the Symposium on National Economy Simulation, Novosibirsk, 1970. 